\title{
Antibacterial Effect of Phytochemial Extracts from Ziziphus-spina christi against Some Pathogenic Bacteria
}

\author{
H.A. Temerk", W.M. Salem, W.F. Sayed and F.S. Hassan* \\ Department of Botany, Faculty of Science, South Valley University and *Department \\ of Medical Analysis, El- Wafaa Clinic, General Authority for Health Insurance, Qena, \\ Egypt.
}

\begin{abstract}
$\mathbf{T}$ HE ANTIBACTERIAL potential of Ziziphus- spina christi as methanol and ethanol extracts, of bark, fruit, roots, seeds and leaves, were evaluated against seven pathogenic bacterial strains using agar well diffusion technique: The used strains were Pseudomonas aeruginosa (ATCC 278223), Enterobacter cloacae (ATCC 13047), Enterobacter aerogenes (ATCC 13084), Escherichia coli (ATCC 25922), Klebsiella pneumoniae (ATCC 13888), Enterococcus faecalis (ATCC 29212) and Methicillin-resistant Staphylococcus aureus (MRSA, ATCC 43300). The antibiotic erythromycin was used as positive control. The presence of phytochemical compounds in the extracts was determined qualitatively, the functional bioactive groups were characterized by FTIR and the presence of bioactive elements was characterized by XRF. Antibacterial activity against the used bacterial strains was assessed by determining the minimal inhibitory and bactericidal concentrations (MIC and MBC) assays. All the used Gram negative and positive bacteria were sensitive to various plant extracts. Bark extract was the most active against all strains except for Enterobacter aerogenes. Ethanol bark extract showed great activity against Enterococcus faecalis with $16.2 \mathrm{~mm}$ clearing zone and MIC, MBC of 15 and $20 \mathrm{mg} \mathrm{ml}^{-1}$, respectively. Methanol bark extract was also effective against Klebsiella pneumoniae with a clearing zone of $16.2 \mathrm{~mm}$ and $20 \mathrm{mg} \mathrm{ml}^{-1}$ for both MIC, MBC. Leaves extracts showed high antibacterial activity against all strains except Escherichia coli. Ethanol fruit extract also exhibited high activity against Pseudomonas aeruginosa with $20 \mathrm{~mm}$ clearing zone and 2.5, $10 \mathrm{mg} \mathrm{ml}^{-1}$ for both MIC and MBC. Finally, ethanol roots showed the largest clearing zone against Enterococcus faecalis $(21 \mathrm{~mm})$ with 10 and $15 \mathrm{mg} \mathrm{ml}^{-1}$ for MIC and $\mathrm{MBC}$, respectively.
\end{abstract}

Keywords: Antibacterial, FTIR, Pathogenic bacteria, Phytochemical constituents, XRF, Ziziphus spina.

\section{Introduction}

Some phytochemicals-plant including flavonoids, tannins, lipids, terpenes, alkaloids, steroids and carbohydrates were extracted from Ziziphus-spina christi (Shahat et al., 2001). These plant extracts and fractions of leaves, fruits and seeds has showed antiviral, antifungal and antibacterial activities and were used in the Egyptian folk medicine for the treatment of several diseases including gastrointestinal tract ailments, diabetes and diarrhea (Shahat et al., 2001). Current antimicrobial therapy for the infectious diseases has certain limitations due to toxicity, side effects and multiple resistance of microorganisms. Enterobacter is usually a commensal bacterium, and is a common opportunistic pathogen responsible for urinary and respiratory tract infections and bacteremia (Talon et al., 2004). Escherichia coli is commonly found in the lower intestinal tract of healthy humans and animals but there are many types of E. coli, a few of which are pathogenic by a variety of infective and toxin-producing mechanisms (EFSA, 2011). S. aureus causes human infections and gastrointestinal illness such as nausea, emesis, abdominal cramps and diarrhea (Scherrer et al., 2004). K. pneumoniae is an opportunistic pathogen that causes hospital- acquired urinary tract infections, pneumonia, septicemias and soft tissue infections, showing co-resistance to quinolones and aminoglycoside antibiotics (Jiang et al., 2008). Currently, there is a continuous search for new drugs with reduced levels of toxicity and side effects (AL-Haj et al., 2010 and Ali et al., 2001). This study was conducted to evaluate the effect of some Ziziphus spina christi extracts, as natural sources of antibacterial activity, on some pathogenic bacterial strains.

\#Corresponding author email: temerk.hanan@gmail.com

DOI: 10.21608/ejbo.2017.665.1035

C2017 National Information and Documentation Centre (NIDOC) 


\section{Materials and Methods}

Bacterial strains and cultural conditions

Seven bacterial strains were provided by Luxor International Hospital at Luxor, Egypt. Including five Gram negative strains were Pseudomonas aeruginosa (ATCC 278223), Enterobacter cloacae (ATCC 13047), Enterobacter aerogenes (ATCC 13084), Escherichia coli (ATCC 25922), Klebsiella pneumoniae (ATCC 13888), and two Gram positive strains were Enterococcus faecalis (ATCC 29212) and Methicillin-resistant Staphylococcus aureus (MRSA, ATCC 43300). All strains were streaked on Mueller- Hinton medium (Mueller \& Hinton, 1941), a pure colony was transferred into agar slant and subculture on Mueller- Hinton medium broth and incubated at $37^{\circ} \mathrm{C}$ for $24 \mathrm{~h}$ before carrying out the test.

\section{Collection of plant material and preparation of extracts}

Different healthy parts of Ziziphus plant were collected from Qena City, Egypt including bark, leaves, fruits, seeds and roots. Extracts were prepared according to Mann et al. (2008) as follows: Samples were washed under tap water followed by distilled water and air- dried at room temperature. Dried samples were ground into coarse powder using a blinder (Fresh-DL 717, Egypt) and packed in clean and dry containers for further use. Ten grams of each sample were dissolved in $100 \mathrm{ml}$ of ethanol and methanol. The solutions were shaken for $72 \mathrm{~h}$ at room temperature using orbital shaker (Stuart scientific, United kingdom) and then filtered by using Whatman ${ }^{\mathrm{TM}}$ no. 1 filter paper. The remaining solvent traces were evaporated by leaving the filtrate at room temperature until completely dry.

\section{Preliminary phytochemical screening of Ziziphus extracts}

Phytochemical screening of the extracts was carried out according to the method described by Trease \& Evans (1989) for the detection of active components as follows:

1 - Alkaloids: $1 \mathrm{ml}$ of $1 \% \mathrm{Hcl}$ was added to $3 \mathrm{ml}$ of the extract in a test tube. The mixture was then heated for $20 \mathrm{~min}$, cooled and filtered, about 2 drops of Mayer's reagent were added to $1 \mathrm{ml}$ of the extract. A creamy precipitate was an indication of the presence of alkaloids.

2- Tannins: $1 \mathrm{ml}$ of freshly prepared $10 \% \mathrm{KOH}$ was added to $1 \mathrm{ml}$ of the extract. A dirty white precipitate showed the presence of tannins.

\section{3- Glycosides}

a) Fehling's method: $10 \mathrm{ml}$ of $50 \% \mathrm{H}_{2} \mathrm{SO}_{4}$ were added to $1 \mathrm{ml}$ of the extract and the mixture heated in boiling water for $15 \mathrm{~min}$. then, 10 $\mathrm{ml}$ of Fehling's solution were then added and the mixture was boiled. Formation of a brick red precipitate was indicated the presence of reducing sugars.

b) Molish's method: Two $\mathrm{ml}$ of the prepared extract were mixed with $0.2 \mathrm{ml}$ of alcoholic solution of $\alpha$-naphthol in addition to 2 $\mathrm{ml}$ of $10 \%$ sulphuric acid, a bluish violet zone is formed indicating the presence of carbohydrates and/ or glycosides.

4- Saponins

a) Frothing test: $2 \mathrm{ml}$ of the extract were vigorously shaken in a test tube for $2 \mathrm{~min}$. A layer of foam was observed indicating the presence of saponins.

b) Emulsion test: 5 drops of olive oil were added to $3 \mathrm{ml}$ of the extract in a test tube and vigorously shaken. Absence of stable emulsion formation indicated the absence of saponins.

5- Flavonoids: $1 \mathrm{ml}$ of $10 \% \mathrm{NaOH}$ was added to $3 \mathrm{ml}$ of the extract. Yellow coloration is indicative for the presence of flavonoids.

6- $\underline{\text { Steroids: }} 5$ drops of concentrated $\mathrm{H}_{2} \mathrm{SO}_{4}$ were added to $1 \mathrm{ml}$ of the extract in a test tube. Appearance of red colour indicates for the presence of steroids.

7- Phlobatannins: $1 \mathrm{ml}$ of the extract was added to $1 \% \mathrm{HCl}$, a positive result indicated by formation of red precipitate.

8- Triterpenes: $1 \mathrm{ml}$ of the extract was added to 5 drops of acetic anhydride and a drop of concentrated $\mathrm{H}_{2} \mathrm{SO}_{4}$. The mixture was then steamed for $1 \mathrm{~h}$ and neutralized with $\mathrm{NaOH}$ followed by addition of chloroform. Development of blue-green color indicates the presence of triterpenes.

Fourier Transform Infrared spectrometer (FTIR)

The presence of bioactive functional groups in different parts of $Z$. spina- christi (bark, fruit, root, leaves and seeds) was determined by fourier transform infrared spectrophotometer (FTIR) in the plant powder. Analysis was carried out using a Magna-FTIR 560 (USA) instrument at a resolution of $2 \mathrm{~cm}^{-1}$ range from 4000 to 400 $\mathrm{cm}^{-1}$ in $\mathrm{KBr}$ pellet using diffuse reflectance 
mode operated by Nicolet Omnic Software as instructed by the manufacturers.

\section{$X$-Ray fluorescence analysis $(X R F)$}

The presence of bioactive elements in the powder of different plant parts was also determined by Energy Dispersive X- ray Fluorescence system (EDXRF). Analysis was carried out using a JEOL JSX 3222 Element analyzer (JEOL, Japan).

\section{Determination of antibacterial activity test of plant} extracts

The antibacterial activity of each extract was tested against the bacterial strains by using agarwell diffusion method (Okeke et al., 2001), The dried extracts (50 mg each) were dissolved in $1 \mathrm{ml}$ of $50 \%$ dimethyl sulphoxide (DMSO). Bacterial strains were inoculated into Mueller- Hinton broth and incubated in a shaking incubator at $150 \mathrm{rpm}$ and $37^{\circ} \mathrm{C}$ for $18 \mathrm{~h}$. The bacterial suspension were spread on the surface of Mueller- Hinton agar by using a sterile cottonswab, then wells were made in the agar plates (four well with"6 mm") for each plate with a sterile cork borer, The wells were then filled with $0.1 \mathrm{ml}$ of each extract using a sterile micropipette and incubated at $37^{\circ} \mathrm{C}$ for $24 \mathrm{~h}$, A blank-well containing 50\% DMSO was used as negative control, also $50 \mathrm{mg}$ of the antibiotic erythromycin (powder were separately dissolved in $1 \mathrm{ml}$ of sterile distilled water) which used as a positive control. The diameter of clearing zones around the well was measured in millimeters and compared to the tested-antibiotic.

Determination of minimum inhibitory concentration (MIC) and minimum bactericidal concentration (MBC)

Minimum inhibitory concentration (MIC) was determined by using the tube dilution technique according to Collins et al. (1995), varying concentration of the extracts were prepared $(200$, $100,50,25 \mathrm{mg} / \mathrm{ml}$ ) and $1 \mathrm{ml}$ introduced into $8 \mathrm{ml}$ of Mueller- Hinton broth in test tube, $1 \mathrm{ml}$ of $18 \mathrm{~h}$ of the bacterial culture diluted to $1 \times 10^{8}$ was added and incubated for $24 \mathrm{~h}$ at $37^{\circ} \mathrm{C}$, by observation the turbidity for each strain, the lowest concentration of the each plant extract that inhibit bacterial growth in the broth culture for each strain is consider as minimum inhibitory concentration (MIC), then the all test tubes were plated out onto MullerHinton agar plates. The plates were then incubated at $37^{\circ} \mathrm{C}$ for $24 \mathrm{~h}$. The number of bacterial colonies developed on each agar plates was counted, and the lowest concentration of extracts that exhibited complete bactericidal effect considered as minimum bactericidal concentration (MBC).

\section{Results}

Phytochemical screening of plant extracts

The presence or absence of some phytochemical groups of compounds in plant ethanol and methanol extracts is presented in Table 1. All extracts had flavonoids, steroids, tannins and glycosides. Phlobatannins were present only in bark extracts. Other phytocomponents varied between different plant parts.

\section{Determination of functional groups by FTIR}

The recorded bands of the FTIR spectrum of the Ziziphus parts and functional groups are shown in Table 2.

$X$-Ray fluorescence analysis (XRF) for bioactive elements in Z. spina- christi

As shwon in Fig. 1, The presence of bioactive elements in the powder of Z. spina-christi parts was determined by using $X$ - ray fluorescence analysis. All plant parts contained calcium, potassium and ferrous iones. The higher percentages of elements were found in different plant parts as follows: potassium in fruit $(71.38 \%)$, calcium in bark (94.23) and ferrous in roots (5.08\%). Other minerals were found such as titanium in roots $(1.06$ $\%$ ), silicon and sulfur in seeds (0.92 and $1.98 \%$, respectively), and copper in leaves $(0.641 \%)$.

\section{Antibacterial activity of plant extracts}

Seven strains of pathogenic bacteria were tested against $Z$. spina - christi plant extracts, five strains were Gram negative rods and two strains were Gram positive cocci (Table 3), The strains of Pseudomonas aeruginosa and Klebsiella pneumoniae were highly sensitive to most extracts, showing MIC varying between $(2.5 \mathrm{mg}-20 \mathrm{mg}$ / $\mathrm{ml})$, for MBC range between $(10 \mathrm{mg}-20 \mathrm{mg} / \mathrm{ml})$. Among Gram negative rods, $P$. aeruginosa was more sensitive to ethanolic extracts especially fruit extract with an inhibition zone of $20 \mathrm{~mm}$ and MIC of $2.5 \mathrm{mg} \mathrm{ml}^{-1}$. The other ethanolic extracts showed antibacterial effects with inhibition zones between $10 \mathrm{~mm}$ to $15 \mathrm{~mm}$. K. pneumoniae growth was inhibited by all Ziziphus extracts with the highest effect recorded for methanol bark extract (inhibition zone $=16.2 \mathrm{~mm}$ ). Enterococcus faecalis was more sensitive to Ziziphus extracts than MRSA especially to methanol fruit extract (inhibition zone $=16.2 \mathrm{~mm})$. MRSA and the other Gram negative rods (Enterobacter cloacae, Enterobacter aerogenes and Escherichia coli) were moderately sensitive to most Ziziphus extracts. 


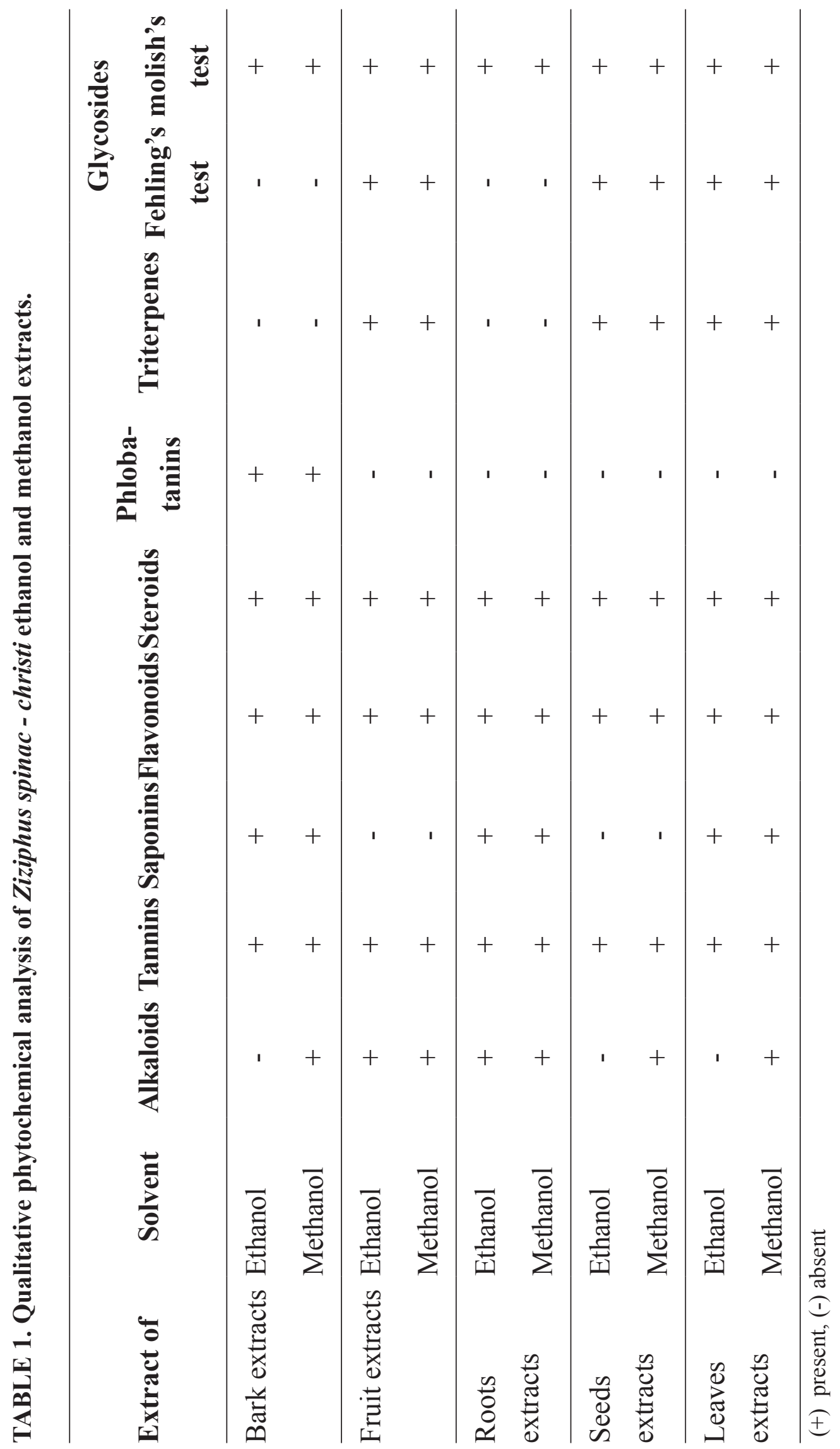

Egypt. J. Bot., Vol. 57, No. 3 (2017) 
TABLE 2. FTIR analysis for bioactive functional groups of Ziziphus plant parts.

\begin{tabular}{|c|c|c|}
\hline $\begin{array}{l}\text { Plant } \\
\text { Part }\end{array}$ & $\begin{array}{l}\text { Wavelength of } \\
\text { peaks }\end{array}$ & Bioactive components \\
\hline \multirow{3}{*}{ Bark } & $3421 \mathrm{~cm}^{-1}$ & $\begin{array}{l}\mathrm{O}-\mathrm{H} \text { bonds in water molecules, or to } \mathrm{OH} \text { groups presented in cellulose, } \\
\text { hemicelluloses and lignin }\end{array}$ \\
\hline & $1617 \mathrm{~cm}^{-1}$ & Stretching vibrations of $(\mathrm{C}=\mathrm{N})$ Amide II of proteins \\
\hline & $1108 \mathrm{~cm}^{-1}$ & $\begin{array}{l}\text { The stretching vibrations of C-O and C-C, C-O-H and C-O-C } \\
\text { deformation of carbohydrates }\end{array}$ \\
\hline \multirow{5}{*}{ Fruits } & $3388 \mathrm{~cm}^{-1}$ & $\begin{array}{l}\mathrm{N}-\mathrm{H} \text { bonds of proteins or } \mathrm{O}-\mathrm{H} \text { bonds in water molecules, or to } \mathrm{OH} \\
\text { groups presented in cellulose, hemicelluloses and lignin }\end{array}$ \\
\hline & $2932 \mathrm{~cm}^{-1}$ & $\begin{array}{l}\text { Stretching of the aliphatic } \mathrm{C}-\mathrm{H} \text { bonds in }-\mathrm{CH} 3 \text { and }-\mathrm{CH} 2 \text { groups in } \\
\text { lipids, cellulose, hemicelluloses and lignin. }\end{array}$ \\
\hline & $1618 \mathrm{~cm}^{-1}$ & $\begin{array}{l}\text { Related to the } \mathrm{C}=\mathrm{O} \text { stretching vibrations of the bonds in the aldehyde } \\
\text { groups of hemicelluloses }\end{array}$ \\
\hline & $1618 \mathrm{~cm}^{-1}$ & $\mathrm{C}=\mathrm{N}$ Amide $\mathrm{I}$ of proteins stretching \\
\hline & $\begin{array}{l}1068,909 \text { and } \\
869 \mathrm{~cm}^{-1}\end{array}$ & $\mathrm{C}-\mathrm{H}$ rocking of $-\mathrm{CH} 2$ bending. \\
\hline \multirow{4}{*}{ Roots } & $3399 \mathrm{~cm}^{-1}$ & $\begin{array}{l}\text { Stretching vibrations of } \mathrm{N}-\mathrm{H} \text { bonds of proteins or } \mathrm{O}-\mathrm{H} \text { bonds in water } \\
\text { molecules, or to } \mathrm{OH} \text { groups presented in cellulose, hemicelluloses and } \\
\text { lignin }\end{array}$ \\
\hline & $2928 \mathrm{~cm}^{-1}$ & Aliphatic $\mathrm{C}-\mathrm{H}-\mathrm{CH} 2-$ and $-\mathrm{CH} 3$ as from of lipids \\
\hline & $1618 \mathrm{~cm}^{-1}$ & $\mathrm{C}=\mathrm{N}$ Amide I vibration \\
\hline & $1054 \mathrm{~cm}^{-1}$ & $\mathrm{C}-\mathrm{H}$ rocking of $-\mathrm{CH} 2$ \\
\hline \multirow{5}{*}{ Seeds } & $3398 \mathrm{~cm}^{-1}$ & $\begin{array}{l}\mathrm{N}-\mathrm{H} \text { stretching of proteins, } \mathrm{O}-\mathrm{H} \text { stretching of hydroxyl groups as from } \\
\text { water or to } \mathrm{OH} \text { groups presented in cellulose, hemicelluloses and lignin }\end{array}$ \\
\hline & $2925 \mathrm{~cm}^{-1}$ & $\mathrm{C}-\mathrm{H}$ stretching of $-\mathrm{CH} 2-$ and $-\mathrm{CH} 3$ as from lipids \\
\hline & $2854 \mathrm{~cm}^{-1}$ & Stretching vibration of $\mathrm{C}-\mathrm{H},-\mathrm{CH} 2-$ and $-\mathrm{CH} 3$ from lipids \\
\hline & $1647 \mathrm{~cm}-^{1}$ & $(\mathrm{C}=\mathrm{N})$ the vibration of Amide I of proteins \\
\hline & $1054 \mathrm{~cm}^{-1}$ & $\mathrm{C}-\mathrm{H}$ rocking of $-\mathrm{CH} 2$. \\
\hline \multirow{3}{*}{ leaves } & $3385 \mathrm{~cm}^{-1}$ & $\begin{array}{l}\mathrm{N}-\mathrm{H} \text { stretching of proteins, } \mathrm{O}-\mathrm{H} \text { bonds in water molecules or to } \mathrm{OH} \\
\text { groups presented in cellulose, hemicelluloses and lignin }\end{array}$ \\
\hline & $1635 \mathrm{~cm}^{-1}$ & $(\mathrm{C}=\mathrm{N})$ vibration of Amide I of proteins \\
\hline & $1058 \mathrm{~cm}^{-1}$ & Amide II of proteins \\
\hline
\end{tabular}



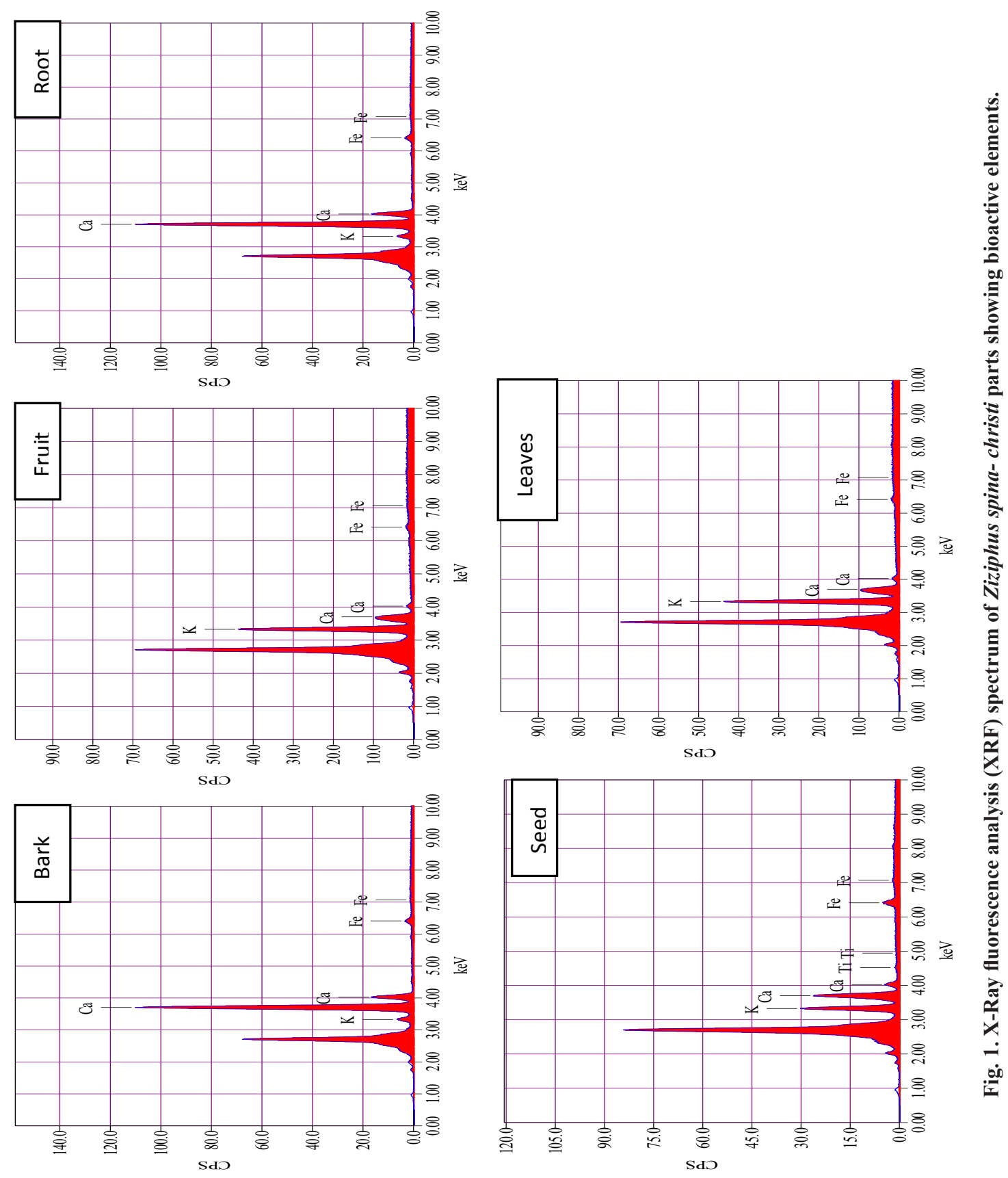

Egypt. J. Bot., Vol. 57, No. 3 (2017) 


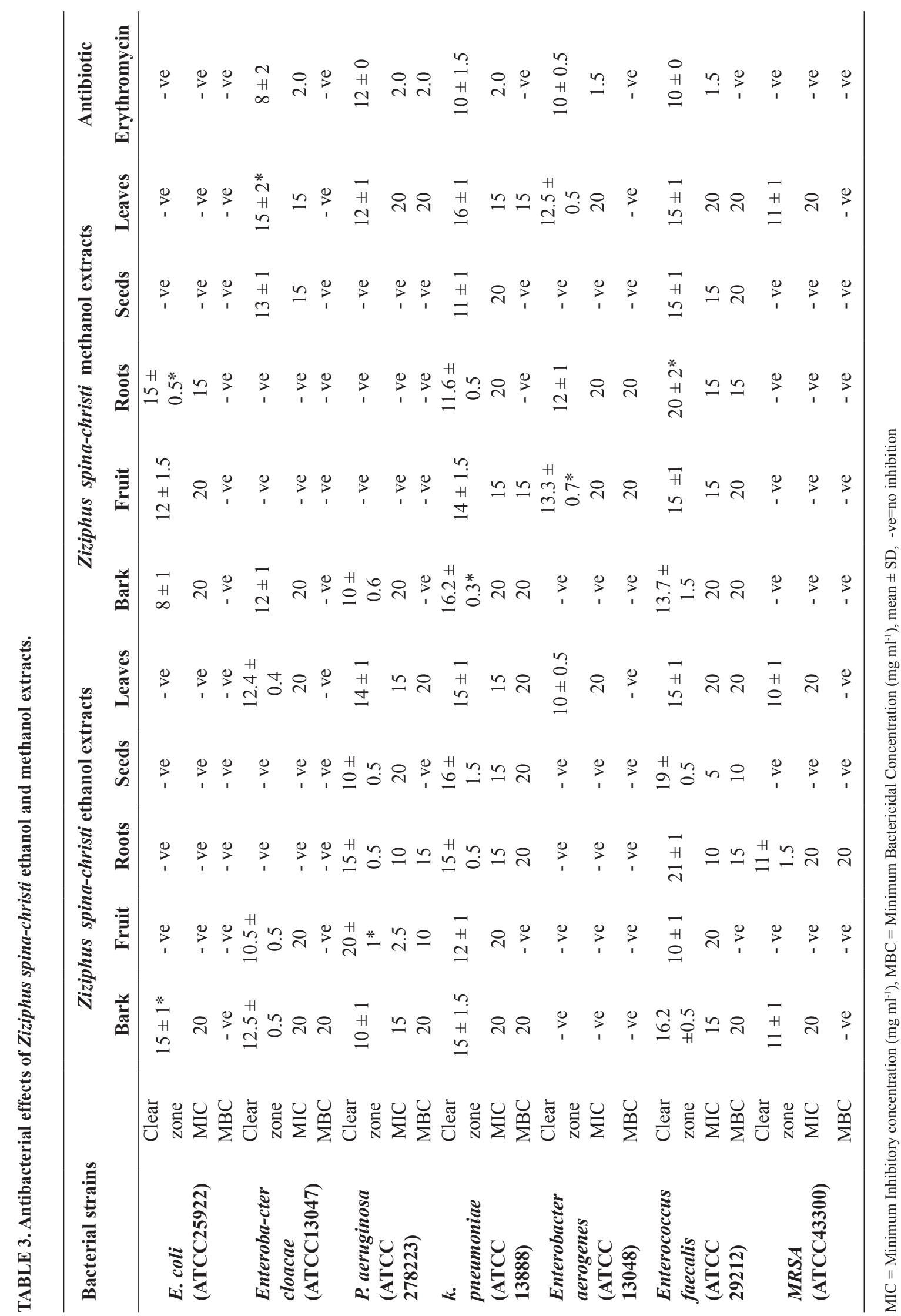




\section{Discussion}

The medicinal plant are important source for bioactive antibacterial phytochemical compound against majority of human pathogenic bacteria, according to our study ethanolic extracts of $Z$. spina-christi of all parts generally are more effective and act as a potential antibacterial agent than the methanolic extract against the tested pathogenic bacterial strains. Bark and leaves extracts were the most active extracts with small variation comparing with the other plant parts extracts, P.aeruginosa as a Gram negative bacteria and E. faecalis as a Gram positive bacteria were are more susceptible to the ethanolic extracts of $Z$. spina-christi of all parts. This activity could be attributed to the presence of tannins and leucocyanidin (Rizk et al., 1993), also due to the presence of other active components like saponins, flavonoids, steroids, Glycosides and Phlobatanins which are known to have antimicrobial properties (Lee, 2006; Lam, 2007 and Ogbunugafor et al., 2008). The antibacterial effect for tannins is due to its ability to react with protein to form stable water-insoluble components, since bacteria cell wall is made up of proteins, detoxifying agents by precipitating the protein components and inhibiting their growth (Dangoggo et al., 2012). In addition, it may bind to proline-rich proteins and interfere with the protein synthesis (Shimada, 2006) .Also, It has been reported to inhibit microbial enzymes (Chung et al., 1998), according to Jacob et al.(1991) and Zablotowicz et al. ( 1996) the complex with metal ions may due to its toxicity as tannic acid which chelate iron from the medium to be in unavailable form to aerobic microorganisms. Also antimicrobial property of saponins attributed to cause leakage of proteins and certain enzymes from the cell and had detergent-like properties that might increase the permeability of bacterial cell membranes without destroying them. The antibacterial effect of alkaloids due to its ability to interchelate with DNA of both Gram positive and negative bacteria and interfere with cell division (Bukar et al., 2015). While Flavonoids activity is likely to be due to their ability to complex with extracellular and soluble proteins and to complex with bacterial cell walls (Marjorie, 1999), inhibit bacterial DNA and RNA synthesis, protein and lipid synthesis (Mori et al, 1987), interfering with energy metabolism in a similar way to respiratory-inhibiting antibiotics, since energy is required for active uptake of various metabolites and for biosynthesis of macromolecules (Haraguchi et al., 1998). Antibacterial properties of steroids are due to association with membrane lipid and exerts its action by causing leakages. So bark extracts were effective against both Gram-positive and Gram-negative bacteria and this agreed with results recorded by El-Kamali \& Mahjoub ( 2009). Each of the seed extracts was effective only against three bacterial strains, this could be attributed to the absence of saponins, phlobatanins and triterpenes as recorded in Epand et al (2007). Ethanol and methanol leaves extracts also were effective against most tested strains and this agrees with that obtained by Al-Mutairi et al. (2016) except for Escherichia coli, also in contrast to their methanolic leaves extract which was more effective than ethanolic extract of leaves. That may be due to the presence of alkaloids in methanol leaves extracts and their absence in ethanol leaves extracts.

\section{Conclusion}

This study showed that ethanolic and methanolic extracts from different parts of $Z$. spina-christi inhibited the growth of various species of Gram positive and Gram negative bacteria. The ethanolic extracts showed slightly better killing action than the methanolic extracts. Ethanol bark extract had an inhibitory effect against all tested bacteria except for Enterobacter aeruginosa, also both ethanolic and methanolic extracts of leaves had an inhibitory effect against all tested strains except for Escherichia coli for both. Pseudomonas aeruginosa and Klebsiella pneumoniae which were highly sensitive to most Ziziphus extracts among Gram negative rods and Enterococcus faecalis among Gram positive strains. Escherichia coli and MRSA were moderately sensitive to most Ziziphus extracts while were resistance to erythromycin.

\section{Refrences}

AL-Haj, N.A., Mashan, M.N., Shamsudin, H., Vairappan, C.S. and Sekawi (2010) Antibacterial activity of marine source extracts against multidrug resistance organisms. Am. J. Pharm. Toxicol. 5, 195-102.

Ali, N.A., Jülich, W.D., Kusnick, C. and Lindequist, U. (2001) Screening of Yemeni medicinal plants for antibacterial and cytotoxic activities. $J$. Hnopharmacol.74,173-179.

Al-Mutairi, M.H., Ali, S., Aly, S.M. and Aldebasi,Y. (2016) Antibacterial activity of sider (Ziziphus spinachristi), leaves extract against selected pathogenic bacteria. European Journal of Pharmaceutical and Medical Research, 3, 138 - 144.

Bukar, A. M., Kyari, M.Z., Gwaski, P. A., Gudusu, M., Kuburi, F.S. and Abadam, Y.I.(2015) Evaluation of phytochemical and potential antibacterial activity 
of Ziziphus spina-christi against some medically important pathogenic bacteria obtained from University of Maiduguri Teaching Hospital, Maiduguri Borno State - Nigeria. Journal of Pharmacognosy and Phytochemistry, 3(5), 98-101.

Chung, K.T., Wong, T.-Y., Wey, C.I., Huang, Y.-W. and Lin, Y. (1998) Tannins and human health, a review. Crit. Rev. Food Sci. Nutr. 38, 421-464.

Collins, G.H., Lynes, P.M. and Grange, J.M. (1995) "Microbiological Methods" (7 $7^{\text {th }}$ ed.), pp.175-190. Butterwort-Heinemann Ltd, Britain.

Dangoggo, S.M., Hassan, L.G., Sadiq, I.S. and Manga S.B. (2012) Phytochemical analysis and antibacterial screening of leaves of diospyros espiliformis and Ziziphus spina-christi. Journal of Chemical Engineering, 1(1), 31-37.

EFSA (2011) (European Food Safety Authority). Shiga toxin-producing E. coli (STEC) O104:H4 outbreaks in Europe: taking stock. EFSA J. 9, 2390.

El-Kamali, H.H. and Mahjoub,S.A. (2009) Antibacterial Activity of Francoeuria crispa, Pulicaria undulata, Ziziphus spina-christi and Cucurbita pepo against seven standard pathogenic bacteria, Ethnobotanical Leaflets. 13, 722-733.

Epand, R.F., Savage, P.B. and Epand, R.M. (2007) Bacterial lipid composition and the antimicrobial efficiency of cationic steroid compounds. Biochimica et Biophysica Acta, 2500-2509

Haraguchi, H., Tanimoto, K., Tamura, Y., Mizutani, K. and Kinoshita, T. (1998) Mode of antibacterial action of retrochalcones from Glycyrrhiza inflata. Phytochemistry, 48,125-129.

Jacob, M.C., Favre, M. and Bensa, J.C. (1991) Membrane cell meabilisation with saponin and multiparametric analysis by flow cytometry. Cytometry, 12(6), 550558.

Jiang, Y.Z.Z., Qian, Y., Wei, Z., Yu, Y., Hu, S. and Li, L. (2008) Plasmid-mediated quinolone resistance determinants qnr and aac (6')-Ib-cr I extended spectrum beta-lactamase-producing Escherichia coli and Klebsiella pneumoniae in China. J. Antimicrob. Chemother. 61, 1003-1006.

Lam, K.S. (2007) New aspects of natural products in drug discovery,Trends Microbiology, 15 (6), 279-289.

Lee, C.P. (2006) Who's in the business of saving lives? J. Med. Philos. 31, 465-482.

Marjorie, C. (1999) Plant products as antimicrobial agents. Clinical Microbiology Reviews, 12, 564-582.
Mann, A., Yahaya, A.Y., Banso, A. and Ajayi, G.O (2008) Phytochemical and antibacterial screening of Anogeissus leiocarpus against some microorganisms associated with infectious wounds. Afr. J. Microb. Res. 2, 60-62.

Mori, A., Nishino, C., Enoki, N. and Tawata, S. (1987) Antibacterial activity and mode of action of plant flavonoids against Proteus vulgaris and Staphylococcus aureus. Phytochemistry, 26, 2231-2234.

Mueller, J.H. and Hinton, J. (1941) A protein -free medium for primary isolation of the Gonococcus and Meningococcus. Proc. Soc. Exp. Biol. Med. 48, 330-333.

Ogbunugafor, H.A., Okochi,V.I., Okpuzor, J. and Emeka, P. (2008) Tolerance and antiplasmodial screening of Ritchea longipedicellata in Plasmodium berghei. Biokemistri. 20 (1), 23-27.

Okeke, M.L., Ireogbu,C.U., Eze, E.N., Okoli, A.S. and Esimone, C.O. (2001) Evaluation of extracts of the root of Landolphia owerrience for antimicrobial activity. J. Ethnopharmacol. 78, 119-127.

Rizk, A.M., Hammouda, F.M., Ismail, S.I. and Hussiney, H.A. (1993) Constituents of plants growing in Qatar Xxiii. Flavonoids of F. Crispa. Qater University. Sci J. 13 (1), 51-52.

Scherrer, D., Corti, S., Muehlherr, J.E., Zweifel, C. and Stephan, R. (2004) Phenotypic and genotypic characteristics of Staphylococcus aureus isolates from raw bulk-tank milk samples of goats and sheep. Veterin. Microbiol. 101,101-107.

Shahat, A.A., Pieters, L., Apers, S., Nazeif, N.M., AbdelAzim, N.S., Berghe, D.V. and Vlietinck, A.J. (2001) Chemical and biological investigations on Zizyphus spina-christi L. Phytother Res. 15 (7), 593- 597.

Shimada,T. (2006) Salivary proteins as a defense against dietary tannins. J. Chem. Ecol. 32 (6), 1149-1163.

Talon, D., Menget, P., Thouverez, M., Thiriez, G., Gbaguidi Haore, H., Fromentin, C., Muller, A. and Bertrand, X. (2004) Emergence of Enterobacter cloacae as a common pathogen in neonatal units: pulsed-field gel electrophoresis analysis. J. Hosp. Infect. 57, 119-125. doi:10.1016/j.jhin.2004.01.023. PMID. : 15183241

Trease, G.E. and Evans, W.C. (1989) "Pharmacognosy" $13^{\text {th }}$ ed, Bailere Traiadal, London p. 69.

Zablotowicz, R.M., Hoagland, R.E. and Wagner, S.C. (1996) Effect of saponins on the growth and activity of rhizosphere bacteria. Adv. Exp. Med. Biol. 405, 83-95.

(Received 14/2/2017; accepted 26/ 9 /2017) 


\section{التأثير المضاد للبكتريا للمستخلصات النباتية للسدر (النبق) على بعض انواع من البكتريا \\ الممرضة}

حنان عبد القتاح تميرك، وسام محمد على سالم، وائل فرغلي سيا و فاطمة صلاح حسن"

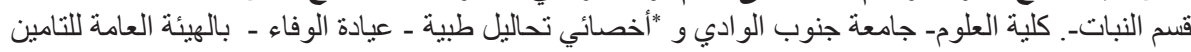

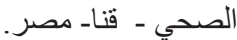

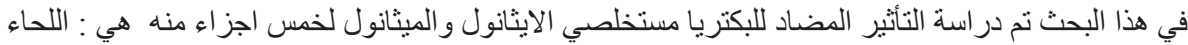

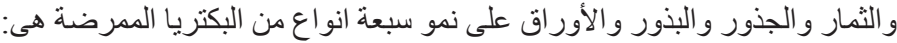

Pseudomonas aeruginosa (ATCC 278223), Enterobacter cloacae (ATCC 13047), Enterobacter aerogenes (ATCC 13084), Escherichia coli (ATCC 25922), Klebsiella pneumoniae (ATCC 13888), Enterococcus faecalis (ATCC 29212) and Methicillinresistant Staphylococcus aureus (MRSA, ATCC 43300).

وتم استخدام مضاد حيوي (اريثروميسين) على نفس السلالات البكتيرية ككونترول إيجابي ـ تم تقدير

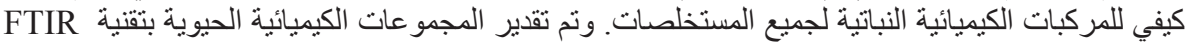

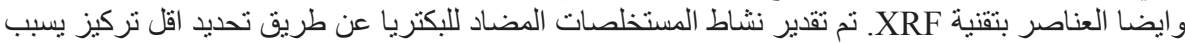

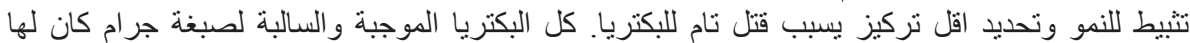

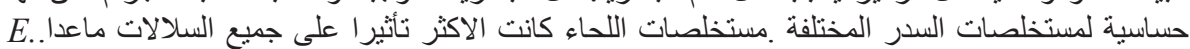
aerogenes

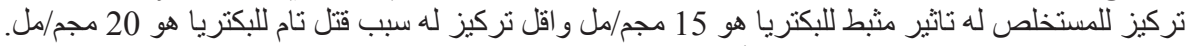

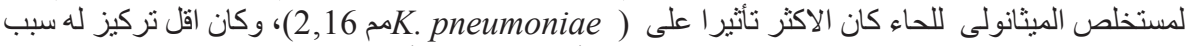

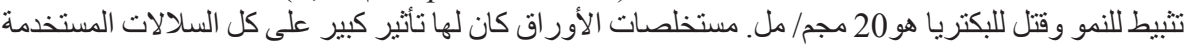

ما عدا Eoli coli

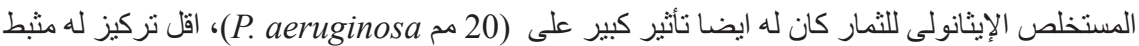

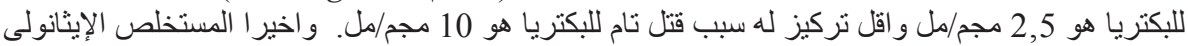

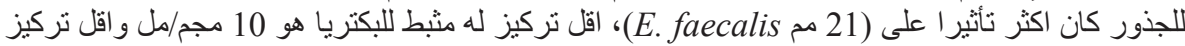

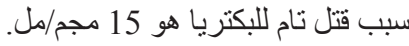

